11. Agreement on the withdrawal of the United Kingdom of Great Britain and Northern Ireland from the European Union and the European Atomic Energy Community, and Protocol on Ireland/Northern Ireland, 24.01.2020. OJ. L 29, 31.1.2020, p. 7-187.

12. Memorandum of Understanding between the Government of the United Kingdom of Great Britain and Northern Ireland and the Government of Ireland concerning the Common Travel Area and associated reciprocal rights and privileges, 8 May 2019. URL: https://assets.publishing.service.gov.uk/government/uploads/system/uploads/ attachment_data/file/800280/CTA-MoU-UK.pdf

13. Joint statement of 8 May 2019 between the UK Government and Government of Ireland on the CTA, 8 May 2019. URL: https://www.gov.uk/government/publications

DOI https://doi.org/10.30525/978-9934-588-92-1-95

\title{
STATE AND INDIVIDUAL RESPONSIBILITY IN INTERNATIONAL PUBLIC LAW: A CONCEPTUAL DISTINCTION
}

\author{
Grabovich T. A. \\ Candidate of Juridical Sciences \\ Vinnitsa, Ukraine
}

It is a settled principle that states incur international responsibility when they breach international obligations, and all the more so when these breaches are particularly serious. On the other hand, today it is undisputed that international law provides for the criminal responsibility of those individuals who commit international crimes. What is much more uncertain is the relationship between these two regimes of international responsibility, that is, the connections between state and individual responsibility when the same or analogous conduct, performed respectively by individuals and by states, gives rise to both individual and state crimes [1, p. 1].

Concurrence between state responsibility and individual responsibility can be relevant from a practical perspective. For instance, findings pertaining to individual responsibility may influence subsequent determinations on state responsibility. Concurrence also is relevant from a theoretical perspective. It raises the question of whether the principles of 
state responsibility in case of concurrence differ from 'ordinary' cases of state responsibility. This question leads to the grand themes of the unity of state responsibility, the transparency of the state and the ('criminal', 'civil', or sut generis) nature of state responsibility [2, p. 615].

There must be a clear understanding that individuals are not "usual" subjects of international public law because individuals don't have the same international legal personality as states and international intergovernmental organizations. For instance, individuals can't adopt an international agreements, they don't create the rules of international law; individuals are not a party to international agreements; individuals are under jurisdiction of the state. Respectively individuals and states are not equal subjects.

But in the meantime, individuals have some elements if international legal personality:

Firstly, locus standi (the right to bring an action, to be heard in court) before the international Courts (ECHR, Inter-American Court of Human Rights). Individuals have a right to protect their rights and freedoms before the International human rights Courts. Thus, on many occasions the Hague International Court recognized officially in its decisions that an individual could not be deprived of his right by reference to international law (Decision No. 7), as well as to the fact that a State may agree to provide an individual his/her own legal competences formulated in international law so that the individual could speak in international courts directly, without preliminary legal documentation of this step (Advisory Opinion No. 15) [3, p. 23].

For instance, the European Convention and the case-law of the European Court make a marked impact on the legislation and case-law of the European States. Thus, the international legal mechanism for human rights and freedoms protection provides an impulse in European space for an improvement of this mechanism within States, providing an individual citizen with «double legal security». This results in an entirely new paradigm of the legal status of an individual [3, p. 35].

Secondly, individuals may be responsible under international law only in certain cases - for commitment of international crimes stricto sensu.

Responsibility of individuals under international law has the following features. International responsibility of individuals has only developed in the criminal field, and only in comparatively recent times. Since the Second World War real forms of individual criminal responsibility under international law have developed. First steps were taken with the establishment of the Nuremberg and Tokyo war crimes tribunals in 1945 and 1946. And later, in 1993, 1994 the UN Security Council created the International Criminal Tribunals for Yugoslavia and Rwanda. And then in 1998 the Rome Statute of the International Criminal Court was adopted. For 382 
instance, the ICC has jurisdiction to prosecute individuals only for the four international crimes (genocide, crimes against humanity, war crimes, crime of aggression). Thus, the acts for which individuals may be responsible in the international legal order are entirely different, than acts of States.

To summarize the status of the individual in international law: since Nuremberg and Tadic' we have known that individuals have criminal law obligations under the laws of armed conflict. Despite doctrinal reticence to accord individuals subjectivity, individuals are now seen as having not only criminal law obligations but also rights under international law [4, p. 30]. Indeed, "the individual has become an increasingly recognized subject of international law in many areas. She has acquired many human rights, and has the obligation to respect international criminal law. This does not mean that the individual is on par with the State as a subject of international law, however" [5, p. 1089].

When states are responsible for wrongful acts, this is about the law of international responsibility. When an individual is responsible under international law, this is about the international criminal law.

Individuals cannot incur international public responsibility. Individuals are not subjects of international public responsibility, even if they commit an wrongful act as a state officials. For such actions they also bear criminal responsibility according national criminal law or international criminal responsibility (for instance, for genocide), if such is provided by international rules.

A simultaneous responsibility may be incurred, for instance, international responsibility of Germany as a state after Second world war and individual international criminal responsibility of certain persons under Nuremberg Tribunal. These are different levels of responsibility.

Thus, individuals may be responsible under international law only for the commission of specific international crimes. States are responsible under international law for breaches of all its international obligations.

\section{References:}

1. Beatrice I. Bonafè. The Relationship Between State and Individual Responsibility for International Crimes. Martinus Nijhoff Publishers, 2009. $281 \mathrm{p}$.

2. Nollkaemper A. Concurrence between Individual Responsibility and State Responsibility in International Law The International and Comparative Law Quarterly. 2003. Vol. 52, No. 3 (Jul.). P. 615-640.

3. Kovler A. The Individual as a Subject of International Law (Discussion Revisited). Law of Ukraine. 2013. № 2. C. 19-41. 
4. Clapham A. The Role of the Individual in International Law. The European Journal of International Law. 2010. Vol. 21 № 1. P. 25-30.

5. Giorgetti C. Rethinking the Individual in International Law. Lewis \& Clark L. Rev. 2019. Vol 22. P. 1085-1149.

DOI https://doi.org/10.30525/978-9934-588-92-1-96

\title{
ІМПЛЕМЕНТАЦІЯ СТАНДАРТІВ ЗАХИСТУ ЕКОЛОГІЧНИХ ПРАВ ЛЮДИНИ, ЗАКРІПЛЕНИХ УГОДОЮ ПРО АСОЦІАЦІЮ МІЖ УКРАЇНОЮ ТА ЄС, В НАЦІОНАЛЬНЕ ПРАВО УКРАЇНИ
}

\author{
Лихогляд В. П. \\ аспірантка кафедри міжнародного права \\ Інститута міжнародних відносин \\ Київського національного університета імені Тараса Шевченка \\ м. Київ, Украӥна
}

Забезпечення прав людини екологічного спрямування, зазначених в Угоді про Асоціацію між Україною, з однієї сторони, та Європейським Союзом, Свропейським Співтовариством 3 атомної енергії і їхніми державами-членами, з іншої сторони є обов'язком держави, виконання якого означає, що Україна імплементує міжнародні стандарти екологічних прав людини.

Розділ 6 Угоди, «Навколишнє середовище», передбачає, що сторони співпрацюють щодо охорони навколишнього середовища, шляхом сприяння реалізації довгострокових цілей сталого розвитку. Стаття 361 Угоди зазначає, що кліматичні зміні є регіональними та глобальними проблемами навколишнього середовища. Стаття 365 стосується імплементації кліматичної політики, і відсилає нас до Додатку XXXI, який передбачає три основні напрямки роботи у сфері зміни клімату:

a) імплементацію Кіотського протоколу разом 3 критеріями його відповідності для повного запровадження кіотських механізмів;

б) розробку довгострокового плану дій щодо пом'якшення кліматичних змін та подальшої адаптації до них;

в) розробку та запровадження довгострокових заходів для скорочення викидів парникових газів [1].

Відповідно до Додатка XXX, Україна повинна адаптувати своє законодавство до більш ніж двох десятків директив та трьох 384 